\title{
@®@ As ideias abstratas em Locke como solução para o problema dos universais
}

\author{
Danival Lucas da Silva*
}

Resumo: O objetivo desse artigo é analisar o impacto da proposta de Locke, em relação às ideias abstratas, na discussão em torno do problema dos universais. Para Locke, a solução desse problema passa pela rejeição do realismo - teoria fortemente defendida pela tradição e ainda presente no pensamento filosófico nos dias de hoje. Nesse artigo falaremos sobre os avanços conquistados pelo empirista inglês e discutiremos os pontos frágeis de seus argumentos. Defenderemos que é possível construir uma refutação definitiva do realismo, baseando-nos no conceito de ideias abstratas e nas evidências reveladas pelo avanço das ciências.

Palavras-chave: Locke. Ideias abstratas. Problema dos universais. Realismo.

\footnotetext{
* Aluno de graduação do curso de Filosofia da UFU. Pesquisa registrada na PróReitoria de Pesquisa e Pós-graduação (ProPP) na modalidade Projeto de Pesquisa de Iniciação Científica Voluntária (PIVIC). Esse projeto de Iniciação Científica foi realizado sob a orientação do Professor Marcos César Seneda, integrando parte de suas atividades como Bolsista de Produtividade PQ do CNPq.
} 


\title{
Abstract ideas in Locke as a solution to the problem of universals
}

\begin{abstract}
The purpose of this article is to analyze the impact of Locke's proposal, in relation to abstract ideas, in the discussion around the problem of universals. For Locke, the solution to this problem requires the rejection of realism - a theory strongly defended by tradition and still present in philosophical thought today. In this article we will talk about the advances achieved by this english empiricist and discuss the weak points of his arguments. We will argue that it is possible to construct a definitive refutation of realism, based on the concept of abstract ideas and on the evidences revealed by the advancement of science.
\end{abstract}

Keywords: Locke. Abstract ideas. Problem of universals.

\section{INTRODUÇÃO}

No contexto do problema dos universais, John Locke apresenta suas considerações em relação à origem dos termos gerais e à natureza das ideias abstratas ou ideias gerais. Para Locke, a solução do problema passa pela rejeição do realismo, fortemente defendido pela tradição e ainda presente no pensamento filosófico nos dias de hoje. Nesse artigo mostraremos os avanços nesse sentido conquistados pelo empirista inglês, bem como os pontos frágeis de seus argumentos. Defenderemos 
que é possível construir uma refutação definitiva do realismo, baseando-nos no conceito de ideias abstratas e nas evidências reveladas pelo avanço das ciências. Primeiramente faremos algumas considerações gerais em relação ao problema dos universais, identificando a abordagem a ser contestada. Em seguida discutiremos as ideias abstratas em Locke, posicionando-o nas correntes conceitualista e convencionalista. Mostraremos que o realismo platônico é plenamente descartado, assim como o realismo aristotélico em sua versão escolástica - embora o realismo aristotélico puro seja admitido como possível. Em todos esses pontos, destacaremos algumas inconsistências em seus argumentos, à luz do conhecimento científico disponível atualmente, e apresentaremos caminhos alternativos que podem sustentar a plausibilidade de suas hipóteses.

\section{O PROBLEMA DOS UNIVERSAIS}

O problema dos universais atravessa praticamente toda a história da filosofia. Surge na metafísica de Platão e Aristóteles, ganha força no debate medieval, alcança a epistemologia dos modernos e chega até nós hoje como um problema ainda em aberto. Segundo a enciclopédia de filosofia da universidade de Stanford, esse problema pode ser definido como um conjunto historicamente variável de questões metafísicas, lógicas e epistemológicas intimamente relacionadas, ligadas, em última análise à seguinte questão: como é possível a cognição universal de 
coisas singulares? ${ }^{1}$ (KLIMA, 2017, p. 1). Tomemos o termo geral "homem" como exemplo. Dizemos que este é um termo universal pois se aplica a todos os homens individuais. Mas essa relação, longe de ser trivial, revela-se um dos maiores desafios do pensamento filosófico em todos os tempos.

Podemos dizer que "o problema medieval dos universais é uma continuação lógica e histórica do antigo problema criado pela teoria de Platão para responder a um tal feixe de questões, a saber, sua teoria das Ideias ou Formas"2 (KLIMA, 2017, p. 1). Os gregos antigos já compartilhavam a noção de que o conhecimento se dá nos universais, e não nos indivíduos particulares. Platão defendia a existência das ideias, transcendentes e anteriores à existência de qualquer indivíduo, como explicação para a capacidade humana de classificação dos particulares em espécies e gêneros. Cada indivíduo particular seria apenas uma cópia imperfeita com algum grau de participação em modelos ou arquétipos eternos e imutáveis. Ao nos deparamos com homens individuais, por exemplo, percebemos a relação destes com o

\footnotetext{
${ }^{1}$ The problem of universals' in general is a historically variable bundle of several closely related, yet in different conceptual frameworks rather differently articulated metaphysical, logical, and epistemological questions, ultimately all connected to the issue of how universal cognition of singular things is possible. (KLIMA, 2017, p. 1)

${ }^{2}$ The medieval problem of universals is a logical, and historical, continuation of the ancient problem generated by Plato's (428-348 B.C.) theory answering such a bundle of questions, namely, his theory of Ideas or Forms. (KLIMA, 2017, p. 1)
} 
modelo universal de homem através do fenômeno da reminiscência e formamos uma ideia em nossa mente que se refere a todos os indivíduos dessa espécie. A palavra "homem", dessa forma, passa a se referir a essa ideia na mente. Esse sistema ficou conhecido como universalia ante rem $^{3}$.

Ao focar nesse problema, Aristóteles, no Livro VII de sua Metafísica, diz: "na verdade, o que desde os tempos antigos, assim como agora e sempre, constitui o eterno objeto de pesquisa, e o eterno problema, é a questão: o que é o ser?" (Metaf. VII, 1028b 2-3). "O que são as coisas", segundo Aristóteles, seria a questão fundamental, cuja solução deveria ser buscada na essência dos seres. Mas a essência, ainda segundo a metafísica aristotélica, está inevitavelmente ligada aos nomes das espécies e dos gêneros nos quais os indivíduos são agrupados. Isso é citado na Metafísica da seguinte forma: "[...] quando perguntamos qual é a sua essência, não dizemos que é branca ou quente ou que tem três côvados, mas que é um homem ou que é um deus." (Metaf. VII, 1028a 15-17). "Homem", como vimos, é, antes de mais nada, um termo geral, um universal. Como bem destacou Platão, termos como esse carregam em si toda uma problemática: A espécie homem existe na realidade? A ideia de homem teria existência

\footnotetext{
${ }^{3}$ Universal antes da coisa. Para Platão, os universais têm status ontológico superior aos indivíduos que deles participam. A existência dos universais é anterior e independente da existência dos particulares.
} 
independente da existência dos seres humanos? Aristóteles resolve a questão alegando que a essência dos seres está na forma substancial, presente em cada indivíduo, atuando sobre a potência da matéria e permitindo, assim, que cada um seja devidamente classificado em seu respectivo grupo de espécie e gênero. Segundo esse entendimento, a forma teria uma realidade metafísica - seria a substância (ousia) do ponto de vista ontológico - enquanto a espécie teria apenas uma existência lógica, ou seja, seria o universal pensado pela mente humana. A alma humana, por exemplo, dá forma à carne e aos ossos que constituem os corpos dos indivíduos que classificamos como homem. A forma está nos indivíduos e é o que os torna semelhantes, mas não possui uma existência independente e anterior a eles. Assim a palavra "homem" refere-se à espécie e conseguimos construir na mente a ideia correspondente por sermos capazes de identificar, nas coisas, sua forma substancial. Nesse caso, mesmo considerando, ao contrário de Platão, a espécie e o gênero como não anteriores aos indivíduos, ainda assim o universal seria real, existindo nos particulares. É o que chamamos de universalia in $\mathrm{re}^{4}$.

Entre os medievais, a solução platônica foi seguida por Santo Agostinho, o qual, grosso modo, substitui o mundo das ideias pela

\footnotetext{
${ }^{4}$ Universal na coisa. Para Aristóteles, os universais estão nas coisas, isto é, são as formas substanciais que atualizam a matéria dando origem aos indivíduos de uma espécie. Os universais, portanto, dependem da existência dos particulares.
} 
mente de Deus e a reminiscência pela luz natural. São Tomás de Aquino segue o modelo aristotélico com adaptações para se adequar à tradição cristã. As formas naturais preexistem em potência na matéria. Temos em nós certas sementes (concepções primordiais do intelecto), as quais, pela luz do intelecto agente, são imediatamente conhecidas por meio das espécies abstraídas dos sensíveis. De qualquer forma, toda filosofia cristã baseia-se na hipótese de que as essências dos seres são reais e existem antes dos indivíduos, pelo menos como um projeto na mente do criador.

Todos esses sistemas filosóficos são classificados como realistas, pois defendem a existência dos universais no mundo extramental, ou seja, os gêneros e as espécies existem na realidade, independente de sua concepção na mente humana. A proposta de Locke rompe definitivamente com esses sistemas filosóficos tradicionais, já que sua solução se insere na esteira do conceitualismo ${ }^{5}$. Ele acredita que os universais possuem uma existência apenas na mente humana, ou seja, uma existência após a coisa: universalia post $\mathrm{rem}^{6}$. Considerando que o realismo é tratado, ainda hoje, como uma possibilidade no mundo

\footnotetext{
5 Para os conceitualistas, somente as palavras e os conceitos na mente humana (ideias) podem ser ditos universais (se aplicam aos vários indivíduos de uma espécie). Todas as outras coisas no mundo são particulares. Divergem, assim, dos nominalistas, para os quais somente as palavras são universais, ou seja, as ideias na mente também seriam particulares.

${ }^{6}$ Universal após a coisa. As palavras e/ou as ideias surgem após a existência dos particulares aos quais se referem, por isso dizemos que são universais após a coisa.
} 
filosófico, mostraremos, nas seções subsequentes, que a contribuição de Locke pode ser usada na construção de bons argumentos contra a razoabilidade dessa posição.

\section{A SOLUÇÃO DE LOCKE}

Locke, no terceiro capítulo do terceiro livro de sua obra Ensaio acerca do entendimento humano, expõe sua visão acerca da problemática existente em torno dos termos gerais. Para ele, as ideias abstratas, associadas aos termos gerais, são suficientes para resolver o problema dos universais. Essa pretensão é exposta da seguinte forma: "Todo esse mistério em relação aos gêneros e espécies, que faz tanto barulho nas escolas [...] não é nada além de ideias abstratas, mais ou menos abrangentes, com nomes anexados a elas." ${ }^{\prime 7}$ (E 3, 3, 9) ${ }^{8}$. No decorrer desse capítulo, a teoria das ideias abstratas é desenvolvida.

Logo no primeiro parágrafo, temos uma afirmação importante. Locke nos diz que, mesmo cientes de que a maioria das palavras, quanto ao seu significado, são termos gerais, precisamos reconhecer

\footnotetext{
7 "This whole mystery of genera and species, which make such a noise in the schools [...] is nothing else but abstract ideas, more or less comprehensive, with names annexed to them." (E 3, 3, 9)

${ }^{8}$ Para a obra Ensaio acerca do entendimento humano, de John Locke, utilizaremos o seguinte sistema de citações: a letra " $E$ " identificando a obra, seguida de números indicando respectivamente livro, capítulo e parágrafo.
} 
que "todas as coisas que existem são particulares"9 (E 3, 3, 1). Essa declaração enfática evidencia a postura crítica de Locke em relação ao realismo. Nos parágrafos seguintes ele mostra como as ideias abstratas podem explicar a ligação entre os particulares e os termos gerais.

Inicialmente é apresentada uma breve reflexão acerca da necessidade dos termos gerais. Locke constata que seria impossível existirem nomes próprios para todas as coisas que há no mundo. A mente é incapaz de manter uma ideia distinta para cada ser existente (pássaro, árvore, etc). E mesmo que isso fosse possível, seria inútil, pois não serviria ao principal objetivo da linguagem que é a comunicação e o conhecimento. Apenas algumas coisas possuem nomes próprios devido à necessidade de nos referirmos a elas (pessoas, cidades, rios, etc). Nessas considerações, temos um primeiro argumento contra o realismo: se os termos gerais têm origem nas necessidades humanas de comunicação e conhecimento e nas limitações da mente humana, não se originam dos universais ante rem dos platônicos. Os termos gerais surgem, na verdade, a partir das ideias abstratas, as quais são formadas pela mente humana ao observar as semelhanças existentes entre os particulares. O processo de abstração é apresentado da seguinte forma:

\footnotetext{
9 "All things that exist being particulars, it may perhaps be thought reasonable that words, which ought to be conformed to things, should be so too [...]." $(\mathrm{E} \mathrm{3,3,1)}$
} 
As palavras tornam-se gerais por serem estabelecidas como os sinais das ideias gerais: e as ideias tornam-se gerais separando-se delas as circunstâncias de tempo e de lugar, e quaisquer outras ideias que possam determiná-las para esta ou aquela existência particular. Por este meio de abstração, elas tornam-se capazes de representar mais do que um indivíduo, cada um dos quais, tendo nisto uma conformidade com esta ideia abstrata, é (como o denominamos) desta espécie ${ }^{10}$ (E 3, $3,6)$.

O processo é simples. Partindo, por exemplo, das ideias individuais de Pedro e Paulo, retiramos delas as circunstâncias de tempo e lugar e todas as outras características pelas quais diferem essas duas ideias individuais (altura, idade, cor de pele, etc). Ao final do processo obtemos uma ideia abstrata, capaz de representar esses dois indivíduos. Por fim, estabelecemos a palavra "homem" como um sinal para essa ideia abstrata. Assim somos capazes de nos referirmos diretamente à espécie, sem precisarmos nos referir a cada indivíduo particular. Trata-se de uma oposição ao realismo, já que o universal (a ideia abstrata) é posterior à coisa e existe apenas na nossa mente.

Locke segue em sua análise afirmando que as naturezas gerais são nada mais que ideias abstratas parciais. Partindo das ideias que temos

\footnotetext{
10 "Words become general by being made the signs of general ideas: and ideas become general, by separating from them the circumstances of time and place, and any other ideas that may determine them to this or that particular existence. By this way of abstraction they are made capable of representing more individuals than one; each of which having in it a conformity to that abstract idea, is (as we call it) of that sort." (E 3, 3, 6)
} 
na mente de cada homem particular, formamos a ideia abstrata de homem. A partir das ideias individuais de cada cavalo particular, forma-se a ideia abstrata de cavalo:

Pois que alguém pense, e depois me diga, em que sua idéia de homem difere da de Pedro e Paulo, ou sua idéia de cavalo da de Bucéfalo, a não ser pelo fato de deixar de fora aquilo que é peculiar a cada indivíduo e reter apenas aquelas idéias particulares complexas que coincidem nas várias existências particulares? ${ }^{11}$ (E 3, 3, 9).

Além disso o processo de abstração se repete em vários níveis. Partindo das ideias abstratas de homem e cavalo, por exemplo, excluindo as diferenças e mantendo apenas os aspectos concordantes, podemos chegar à ideia mais geral de animal. O processo segue dessa forma até se chegar aos termos mais gerais: vivens, corpo, substância, ser e coisa. Após expor essa estrutura, Locke conclui: "Em tudo isso é constante e invariável o fato de que todo termo mais geral significa uma ideia desse tipo, e é apenas uma parte de quaisquer outros termos contidos abaixo dele. ${ }^{12}$ " (E 3, 3, 9). É importante notarmos que,

\footnotetext{
11 "For let any one effect, and then tell me, wherein does his idea of man differ from that of Peter and Paul, or his idea of horse from that of Bucephalus, but in the leaving out something that is peculiar to each individual, and retaining so much of those particular complex ideas of several particular existences as they are found to agree in?" (E 3, 3, 9)

1212 "In all which this is constant and unvariable, That every more general term stands for such an idea, and is but a part of any of those contained under it." (E 3, $3,9)$
} 
segundo esse modelo, cada ideia abstrata mais geral (mais acima na hierarquia das ideias) é constituída apenas de partes das ideias que estão abaixo dela. Podemos pensar a ideia abstrata como uma ideia reduzida, consolidada, simplificada.

Dessa forma, para Locke, os universais são ideias abstratas e por isso são criaturas do entendimento: “[...] geral e universal não pertencem à existência real das coisas; mas são as invenções e criaturas do entendimento, feitas por ele para seu próprio uso, e dizem respeito apenas a sinais, sejam palavras ou idéias. ${ }^{13}$ " (E 3, 3, 11). Segundo esse entendimento, apenas sinais podem ser ditos universais; e os sinais (palavras ou ideias) existem apenas em nossa mente. Locke explica que as palavras se tornam gerais quando são usadas como sinais para as ideias gerais. As ideias são gerais quando, como foi demonstrado, passam a representar diversas coisas particulares. Mas as ideias não pertencem universalmente às próprias coisas. As coisas são todas particulares do ponto de vista da existência, isto é, até mesmo os termos gerais e as ideias abstratas, do ponto de vista da existência, são palavras e ideias particulares na mente. Todavia, do ponto de vista de seu significado, são universais. Assim devemos classificar Locke como um conceitualista, como destaca Lovatti em seu artigo. Concordando com

13 “"...] general and universal belong not to the real existence of things; but are the inventions and creatures of the understanding, made by it for its own use, and concern only signs, whether words or ideas." (E 3, 3, 11) 
Vere Chappel, esse autor assume que a expressão "tudo é particular" denominada indevidamente de princípio da metafísica nominalista de Locke - não se aplica à capacidade de representação das ideias (LOVATTI, 2004, p. 3). A ideia abstrata (o conceito) existe de forma particular na mente, mas com capacidade de representação universal. Ou seja, um único conceito se aplica universalmente a vários particulares, que é exatamente a posição defendida pelos conceitualistas. Importante ressaltar que a ideia abstrata de Locke é resultado de um processamento prévio; uma ideia consolidada, que carrega em si apenas a essência das outras ideias particulares que representa.

\subsection{Contra o realismo platônico}

Baseando-se em sua teoria das ideias abstratas, Locke afirma que o realismo platônico é impossível. Além do argumento apresentado inicialmente - tudo que existe é particular e os termos gerais surgem da limitação da mente humana e da necessidade de comunicação e construção de conhecimento -, ele desenvolve a seguinte reflexão:

Mesmo nas substâncias, onde as ideias abstratas
parecem ser tiradas das próprias coisas, elas não são
constantemente iguais; nem mesmo na espécie que nos
é mais familiar e a qual conhecemos mais intimamente
[o homem]: já houve casos de dúvida quanto à
possibilidade de classificar o feto nascido de uma
mulher como homem, gerando debates sobre se ele 
deveria ou não ser nutrido e batizado: o que não poderia ocorrer, se a ideia abstrata ou a essência à qual o nome

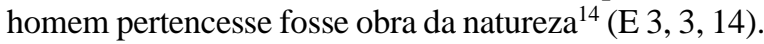

Substância, para Locke, é o substrato ou suporte de inerência dos $\operatorname{modos}^{15}$, por exemplo, o homem. Nesse trecho do capítulo III e, mais detalhadamente, no capítulo VI (Dos nomes das substâncias), Locke destaca o fato de que o significado dos nomes das substâncias pode se mostrar diferente para pessoas diferentes. Há divergência quanto a quais seres individuais consideramos que fazem parte da espécie homem, por exemplo. Imagine um homem adulto "A" amigo de um outro homem adulto "B”, ambos vivendo na Grécia antiga. O grego "A" não considera que o filho recém-nascido de seu amigo possa ser classificado como homem, pois este teria nascido com algum tipo de deficiência física ${ }^{16}$. O grego "B" tem certeza de que seu filho é um

\footnotetext{
14 "Even in substances, where their abstract ideas seem to be taken from the things themselves, they are not constantly the same; no, not in that species which is most familiar to us, and with which we have the most intimate acquaintance: it having been more than once doubted, whether the foetus born of a woman were a man, even so far as that it hath been debated, whether it were or were not to be nourished and baptized: which could not be, if the abstract idea or essence to which the name man belonged were of nature's making." (E 3, 3, 14)

${ }^{15}$ Os modos são combinações de ideias simples que não subsistem por si só. Por exemplo, a beleza seria um modo misto (combinação das ideias simples de cor e figura) inerente a uma substância.

16 Para uma perspectiva mais atual do problema, imagine o caso dos anencéfalos. São bebês que apresentam uma má-formação fetal do cérebro, o que ocasiona uma ausência parcial do encéfalo. Podem nascer sem o córtex cerebral, por exemplo, o que os impossibilita de chegarem à vida adulta e desenvolverem qualquer tipo de pensamento racional.
} 
homem, tem o direito à vida, deve ser nutrido e ser reconhecido perante a sociedade. Locke está dizendo, nesse trecho, que divergências como essa - na classificação dos indivíduos em suas espécies - são indícios de que os universais não são obra da natureza, como querem os realistas platônicos. Se a essência do homem nos fosse revelada, seria improvável que:

[...] para um ele seria animal racional, mas, para outro, animal bípede sem penas. Aquele que anexa o nome à ideia complexa, composta de sentido e movimento espontâneo, unida a um corpo de tal forma, possui, portanto, uma essência da espécie homem; e aquele que, após um exame mais aprofundado, acrescenta racionalidade, tem outra essência da espécie que ele chama de homem: assim, um mesmo indivíduo será um homem verdadeiro para um, mas não para o outro ${ }^{17}(\mathrm{E}$ $3,6,26)$.

Dessa forma, para Locke, divergências como essa na busca de uma definição para o conceito de homem, indicam a impossibilidade da teoria das ideias de Platão. Não seria possível que a ideia abstrata associada ao termo "homem" se revelasse tão diferente para diferentes homens, se fosse obra da natureza.

17 " [...] to one it should be animal rationale, and to another, animal implume bipes latis unguibus. He that annexes the name to a complex idea, made up of sense and spontaneous motion, joined to a body of such a shape, has thereby one essence of the species man; and he that, upon further examination, adds rationality, has another essence of the species he calls man: by which means the same individual will be a true man to the one which is not so to the other." (E 3, 6, 26) 
Além disso, Locke diz que poucas pessoas apontariam "a figura ereta" como a diferença essencial da espécie humana. Mas destaca que é comum classificarmos os animais nos atendo à forma. Reforça também, nesse capítulo, que já foi debatido, mais de uma vez, se fetos humanos devem ser preservados ou batizados "apenas por causa da diferença de sua configuração externa em relação às crianças comuns, sem considerar se não eram tão capazes de raciocinar quanto bebês moldados em outros formatos"18 (E 3, 6, 26) . Portanto, nem mesmo a racionalidade é critério absoluto na classificação de um indivíduo como homem.

Faz-se necessário reconhecer que a posição de Locke apresentada aqui está sujeita à seguinte contestação: a dúvida (ou o erro) em relação à classificação dos indivíduos nas espécies não implica que elas não existam. O grego “A”, por exemplo, pode estar errado ao não classificar o filho de seu amigo como humano; ou a definição de homem como animal bípede sem penas pode estar equivocada. Isso não implica, necessariamente, que Platão esteja errado e não exista a ideia perfeita e imutável de homem, representando sua essência. Mesmo assim podemos acrescentar alguns argumentos às observações de Locke para reforçar sua posição. Hoje sabemos que os gregos não tinham em mente

\footnotetext{
18 " [...] only because of the difference of their outward configuration from the ordinary make of children, without knowing whether they were not as capable of reason as infants cast in another mould." (E 3, 6, 26)
} 
os mesmos indivíduos que nós hoje, quando utilizavam o termo "homem" em seu sentido mais amplo. Além da diferença apontada por Locke em relação às definições "animal racional" e "animal bípede sem penas", podemos acrescentar o conceito utilizado por Aristóteles ao afirmar que o homem é um animal político e que sua natureza o faz ter o domínio da fêmea e do escravo. Ainda segundo o estagirita, o indivíduo fora da polis seria, na verdade, um bicho ou um deus. A essência do homem, portanto, não é a mesma para nós hoje como era no pensamento daquela época. Os casos de crianças selvagens estudados pela antropologia demonstram que temos um conceito de ser humano distinto do de Aristóteles. Dessa forma, segue-se que os gregos antigos não poderiam afirmar que a ideia de "homem" existe no mundo das ideias, se existe um erro na referência do termo "homem" utilizado nessa afirmação ${ }^{19}$. Eles estariam imaginando a existência de uma essência que não inclui indivíduos que nós incluímos hoje, por exemplo. Se existe a ideia eterna e imutável de homem e ela equivale ao que nós hoje conhecemos como ser humano, a ideia a que se referem os gregos antigos ao utilizar o termo "homem", necessariamente, precisa estar errada. Todas as definições citadas - animal bípede sem

\footnotetext{
${ }^{19}$ Utilizamos, aqui, a palavra "referência" no sentido que lhe atribui Frege em seu artigo "Sobre o sentido e a referência" (FREGE, 2011, P. 1). Nesse texto Frege investiga a necessidade de distinção entre os conceitos: sinal, sentido e referência. A referência da palavra (ou sinal) "Sol", por exemplo, seria a estrela que se situa no centro do nosso sistema solar.
} 
penas, animal racional, animal político - estão erradas. Ademais podemos considerar a possibilidade de nós hoje estarmos errados e, que no futuro, o conceito de homem abarque mais indivíduos - um feto de poucas semanas, por exemplo. De qualquer forma, o erro - não a dúvida, mas o erro constatado pelo avanço das ciências - revela uma incoerência no assentimento ingênuo da existência, no mundo das ideias, daquela essência pensada de forma equivocada. $\mathrm{O}$ realismo platônico restaria, desse modo, prejudicado.

\subsection{Contra o realismo aristotélico}

Para Locke o realismo de Aristóteles faz mais sentido. Ele o aceita em sua versão pura - fazendo algumas ressalvas que se inserem na esteira do convencionalismo ${ }^{20}$-, mas rejeita a versão identificada na tradição escolástica, como veremos. Os argumentos que Locke apresenta sobre essa questão se baseiam em sua bipartição do conceito de essência. Para ele existem as essências reais e as essências nominais.

\subsubsection{Essências reais e essências nominais}

Essência real diz respeito à "real constituição interna das coisas, mas geralmente desconhecida nas substâncias, da qual dependem suas

\footnotetext{
${ }^{20} \mathrm{O}$ convencionalismo defende que os termos gerais surgem da convenção entre os homens. É, dessa forma, incompatível com o realismo.
} 
qualidades detectáveis" ${ }^{21}$ (E 3, 3, 15). É o que faz algo ser o que é, a suposta estrutura interna das coisas. O DNA, no caso dos seres vivos, seria, para nós hoje, um bom exemplo de essência real. É aquilo que, presente na constituição interna de todo ser vivo, determina as qualidades observáveis (fenótipo) de cada espécie. A molécula de DNA era desconhecida na época de Locke, o que corrobora a observação, “mas geralmente desconhecida nas substâncias", citada na definição. Essência nominal refere-se à constituição artificial dos gêneros e espécies, ou seja, são as ideias abstratas. Locke sustenta que, apesar de geralmente se supor uma real constituição dos grupos de coisas, é evidente que as ideias abstratas é que são a essência desses grupos: "as ideias abstratas são as essências dos gêneros e da espécie ${ }^{22 "}$ (E 3, 3, 12). Diz também que as essências nominais são trabalho do entendimento, isto é, existem apenas na mente humana: “As essências dos tipos de coisas e, conseqüentemente, a classificação das coisas, é o trabalho do entendimento que abstrai e gera essas idéias gerais ${ }^{23}$ " (E 3, $3,12)$.

\footnotetext{
21 "And thus the real internal, but generally (in substances) unknown constitution of things, whereon their discoverable qualities depend, may be called their essence." (E 3, 3, 15)

22 "Abstract ideas are the essences of genera and species." (E 3, 3, 12)

23 "The essences of the sorts of things, and, consequently, the sorting of things, is the workmanship of the understanding that abstracts and makes those general ideas" $(\mathrm{E} 3,3,12)$
} 
Abordando essa perspectiva, reforça Newton em seu artigo:

Locke admite a possibilidade de que as espécies naturais podem existir. Apesar de parecer um tanto quanto cético em relação a essa possibilidade, não força esse ceticismo. $\mathrm{O}$ argumento aqui é: mesmo que existam espécies naturais, nossas classificações não as descrevem com precisão. (NEWTON, 2014, p. 112)

Portanto, mesmo que exista uma essência real para cada espécie, nós geralmente não as utilizamos em nosso sistema de classificação. $\mathrm{O}$ DNA só foi descoberto recentemente, mesmo assim nós classificamos as espécies de seres vivos desde sempre - segundo Locke, com base nas ideias abstratas, ou seja, com base em sua essência nominal.

Locke analisa, ainda, esses dois tipos de essência (real e nominal) em relação às ideias e modos simples e em relação às substâncias ${ }^{24}$. Nas espécies das ideias e modos simples, essas duas essências sempre coincidem: "Uma figura que limita um espaço entre três linhas é a essência real e nominal de um triângulo; sendo não apenas a ideia abstrata à qual o nome geral está anexado, mas a própria essência ou o

\footnotetext{
${ }^{24}$ Ideias simples são as percebidas passivamente pelos sentidos: cor, cheiro, gosto, figura, movimento, tamanho, extensão, número, prazer, dor, etc. Ideias complexas são formadas pela mente ao comparar, combinar e abstrair as ideias simples. Dividem-se em modos, substâncias e relações. Modos são combinações de ideias simples que não subsistem por si só, ou seja, dependem das substâncias. Dividemse em simples e complexos. Os modos simples são combinações ou variações de um mesmo tipo de ideias simples: uma dúzia é um grupo de doze unidades. Os modos complexos são compostos por ideias simples diferentes: beleza é uma combinação de cor e figura. Substâncias são o substrato ou suporte de inerência dos modos. Relação é o resultado da comparação e reflexão entre ideias.
} 
ser da coisa em si" ${ }^{25}$ (E 3, 3, 18). Mas, nas substâncias, essas duas essências são bem diferentes: "Mas o oposto ocorre no que diz respeito à parcela de matéria que constitui o anel no meu dedo; na qual essas duas essências são aparentemente diferentes."26 (E 3, 3, 18). Ocorre que, geralmente, não temos ideia da real constituição das partes insensíveis das coisas. No caso do material do anel, a cor, o peso e a dureza é que o torna ouro, ou lhe dá o direito a esse nome, que é sua essência nominal. Trazendo para nós hoje, pensando em termos de estrutura interna das moléculas e dos átomos, podemos considerar que a essência real dessas coisas muito simples coincide com a ideia abstrata que criamos em relação a elas. Um átomo de hidrogênio possui um elétron enquanto um átomo de hélio possui dois e essas estruturas diferentes constituem tanto a essência real quanto a essência nominal desses dois tipos de seres.

\subsubsection{Plausibilidade do realismo aristotélico puro e impossibilidade da versão escolástica}

\footnotetext{
25 "A figure including a space between three lines, is the real as well as nominal essence of a triangle; it being not only the abstract idea to which the general name is annexed, but the very essentia or being of the thing itself." (E 3, 3, 18)

26 "But it is far otherwise concerning that parcel of matter which makes the ring on my finger; wherein these two essences are apparently different." (E 3, 3, 18)
} 
Para Locke a solução de Aristóteles é mais compatível com a realidade do que a de Platão:

Mais racional é a opinião daqueles que consideram que todas as coisas naturais têm uma constituição real, porém desconhecida, de suas partes insensíveis; de onde fluem aquelas qualidades sensíveis que nos servem para distingui-las umas das outras $[\ldots]^{27}$ (E 3, 3, 17).

Assim, como vimos, Locke refuta completamente a possibilidade do chamado universal ante rem dos platônicos e medievais, mas considera a possibilidade da existência do universal in re dos aristotélicos. Contudo é importante destacar que a suposta real constituição das coisas é geralmente desconhecida, provocando os problemas discutidos anteriormente. Dessa forma é inútil supor que as espécies, relacionadas aos termos gerais que utilizamos na linguagem, são previamente dadas pela natureza. Pelo contrário, na maioria dos casos são resultado de convenção, pois utilizamos as essências nominais, as quais podem ser diferentes para pessoas diferentes.

Apesar disso Locke reconhece que as essências têm seu fundamento na similitude das coisas. Ele não nega que "a natureza, na produção das coisas, faz várias delas semelhantes" 28 (E 3, 3, 13). Isso,

\footnotetext{
27 "More rational opinion is of those who look on all natural things to have a real, but unknown, constitution of their insensible parts; from which flow those sensible qualities which serve us to distinguish them one from another." (E 3, 3, 17)

28 " [...] Nature, in the production of things, makes several of them alike." (E 3, 3, 13)
} 
segundo ele, pode ser facilmente observado nas raças dos animais e em todas as coisas propagadas pela semente. Mas, insiste Locke, "a classificação delas sob nomes é o trabalho do entendimento que se aproveita da semelhança observada entre elas para criar ideias gerais abstratas [...]"29 (E 3, 3, 13). Assim, mesmo que existam estruturas internas criadas pela natureza, chamadas de essências reais, não são elas que determinam o trabalho humano de classificação dos seres em espécies, que se dá segundo o processo de abstração explicado anteriormente, o qual se baseia nas características externas e, por isso mesmo, está sujeito a erros.

Locke segue dizendo que "as supostas essências reais das substâncias, se diferentes de nossas idéias abstratas, não podem ser as essências das espécies nas quais classificamos as coisas"30 (E 3, 3, 13). Nesse ponto percebemos como Locke afasta a possibilidade do realismo aristotélico na forma em que foi incorporado pelos escolásticos, como explica Lovatti em seu artigo:

Sua preocupação constante, que é evidente no tratamento da questão complexa da relação entre a essência real e a nominal, é refutar a visão dos

\footnotetext{
29 " [...] the sorting of them under names is the workmanship of the understanding, taking occasion, from the similitude it observes amongst them, to make abstract general ideas." (E 3, 3, 13)

30 "And therefore the supposed real essences of substances, if different from our abstract ideas, cannot be the essences of the species we rank things into." (E 3, 3, 13)
} 
escolásticos, de acordo com a qual um conceito universal na mente (post rem) reflete o universal presente em todas as coisas como forma substancial (o universal in re) (LOVATTI, 2004, p. 3).

Os escolásticos, seguindo Aristóteles, acreditavam no universal presente nas coisas (a alma humana, por exemplo). O que os difere do aristotelismo puro é que, para eles, os universais têm uma existência anterior. Como o homem é uma criatura, a ideia de homem deve existir antes na mente do criador (Deus). E nós somos capazes de captar essas ideias universais, ao nos deparamos com os particulares, porque contamos com algum tipo de auxílio divino (intelecto agente). Por isso, para os escolásticos, o universal na mente reflete o universal nas coisas. Locke não se afasta completamente da possibilidade da existência do universal nas coisas de Aristóteles, como vimos, mas nega que esse universal real possa refletir, necessariamente e em todos os casos, o universal nominal, ou seja, o conceito que temos na mente.

Isso significa que existe a possibilidade de uma coincidência entre as essências reais e nominais, pelo menos para algumas espécies. Mas tal fato ocorreria por acaso, não por necessidade. Nos casos onde a essência real difere da ideia abstrata (essência nominal), o que vale para nós, no trabalho de classificação, é a ideia abstrata, pois é a "entidade" a que temos acesso. A estrutura interna pode estar fora do nosso alcance - como o DNA estava fora do alcance do conhecimento disponível aos empiristas ingleses. Dessa forma os nomes das espécies são contingentes, como também ocorre com os indivíduos considerados 
pertencentes a determinado grupo. Negros e índios nem sempre foram considerados como pertencentes à espécie humana. Locke está justamente afirmando que nosso processo de classificação é falho. $\mathrm{O}$ resultado provavelmente seria outro se tivéssemos acesso às estruturas internas em todos os casos de formação de termos gerais, na identificação de todas as espécies de seres do mundo.

Referindo-se a essa questão, Kuklok examina, em seu artigo, a arbitrariedade na formação das espécies em Locke. Ele cita a chamada "passagem do relógio" (E 3, 6, 39 APUD KUKLOK, 2018, p. 3) e afirma que, nesse trecho, Locke mostra "a irrelevância das diferenças internas para as espécies, cujos limites são estabelecidos previamente ao nível de fenômeno" (KUKLOK, 2018, p. 2). Nessa passagem, Locke diz que há relógios com estruturas internas (partes mecânicas) diferentes e, a partir disso, lança uma questão: algumas dessas diferenças (ou todas elas) seriam suficientes para produzir uma diferença específica na mente de um relojoeiro? Ou seja, a estrutura interna das coisas, naqueles casos onde as conhecemos, é o que dá origem às espécies e aos termos gerais? Kuklok diz que, para Locke, mesmo nesses casos, as diferenças internas são irrelevantes. Classificamos as espécies pelas características externas.

Nesse mesmo sentido, destaca Newton, em seu artigo, sobre a possibilidade do convencionalismo em Locke. Para esse autor, Locke chama nossa atenção para o fato de que "nossos sistemas de 
classificação são questões de interesse e convenção humanos e consideram as semelhanças que observamos nas coisas" (NEWTON, 2014, p. 105). Newton vê em Locke uma preocupação em “demonstrar que nossos sistemas atuais de classificação são mal construídos e não espelham as espécies naturais; e isso é verdade independentemente da existência ou não das essências reais" (NEWTON, 2014, p. 105). Ou seja, mesmo que existam estruturas internas semelhantes, nós classificamos os seres em espécies por convenção, observando as características externas. $\mathrm{O}$ autor cita também trechos do sexto capítulo do livro três do Ensaio:

Locke argumenta que, desde que as essências reais das coisas nunca foram consideradas pela maior parte homens, elas não podem ser a base da classificação (III. vi. 24). Ele então argumenta que, mesmo que tal descoberta fosse feita, seria irrelevante, uma vez que os idiomas, em todos os países, foram estabelecidos muito antes das Ciências (III. vi. 25) (NEWTON, 2014, p. 107).

$\mathrm{O}$ argumento de que a linguagem surge antes das ciências é fortíssimo. Os termos gerais fazem parte da linguagem e a linguagem é criada por homens comuns. Esse processo, obviamente, independe das descobertas científicas a respeito da constituição interna das coisas. Logo os universais não refletem, necessariamente, a forma substancial das coisas. O agrupamento de indivíduos em espécies depende, portanto, do acordo entre os homens, o que nos leva ao convencionalismo. 
Assim sendo o realismo aristotélico na versão escolástica é satisfatoriamente afastado. Por outro lado, percebemos que Locke não consegue afastar definitivamente o realismo aristotélico puro.

\subsubsection{Refutação definitiva}

No sexto capítulo do terceiro livro do Ensaio, Locke menciona o problema das gradações contínuas. Podemos pensar esse problema da seguinte maneira. Ao classificarmos um número determinado de seres diferentes em grupos, se as diferenças se dão por gradações contínuas, a classificação é arbitrária e os grupos se formarão por convenção. As cores são um bom exemplo desse problema. Cada tonalidade é, na verdade, o efeito produzido em nós pela luz oscilando em uma determinada frequência de onda. Em outras palavras, uma cor é uma onda eletromagnética de determinado comprimento, situando-se dentro do espectro visível (de aproximadamente 400 a 750 nanômetros). Como a diferença entre os comprimentos de onda se dá por gradações contínuas, não é possível dizer que o amarelo, por exemplo, é dado pela natureza. Por convenção, chamamos de amarelo as ondas eletromagnéticas de comprimento entre aproximadamente 570 e 590 $\mathrm{nm}$. Ao observarmos um objeto refletindo luz de comprimento $580 \mathrm{~nm}$, por exemplo, a maioria de nós identificaria com facilidade que se trata de um objeto amarelo, pois esse tom particular de cor está no centro do grupo que recebe esse nome. Mas ao aproximarmos dos limites do 
grupo, a identificação tende ao impossível. Imagine o comprimento de onda próximo a $590 \mathrm{~nm}$ e a dúvida se o objeto é amarelo ou laranja estará posta. E o problema não se resolve se utilizarmos aparelhos cada vez mais precisos para realizar uma medição e indicar a classificação, pois poderemos sempre imaginar uma tal proximidade ao limite do grupo - uma onda de 589,999... nm, por exemplo - que supere a precisão do melhor equipamento que possa ser construído pelo homem. Isso porque o comprimento das ondas varia de forma contínua e não discreta; e a precisão de qualquer máquina nunca será infinita. Por outro lado, no caso de classificação de seres cujas diferenças podem ser pensadas de forma discreta, o problema de identificação de um indivíduo como pertecente a um grupo pode ser eliminado, mas, mesmo assim, a definição dos grupos continua sendo arbitrária e não dada pela natureza, a menos que seja possível observar lacunas (as diferenças ocorrerem em saltos). Enfim, o problema das gradações contínuas pode ser facilmente observado em diversas outras situações do dia a dia. Onde termina o rio e começa o mar? Qual é o limite entre a Terra e o espaço? ${ }^{31}$ Qual o tamanho mínimo de um corpo celeste para

\footnotetext{
${ }^{31}$ Esses dois primeiros exemplos (rio e mar; Terra e espaço) foram inseridos apenas para ilustrar situações de gradações contínuas muito fáceis de serem observadas. Contudo referem-se ao problema da identificação dos limites dos corpos, o qual será trabalhado no futuro. Nesse artigo, nossa investigação será restrita ao problema da classificação de indivíduos em espécies, como ilustramos nos dois exemplos seguintes.
} 
ser classificado como planeta $?^{32}$ Em que momento exato da gestação um bebê deixa de ser embrião e se torna feto? São inúmeros os casos em que as espécies não são dadas pela natureza e precisamos classificar os indivíduos em grupos ${ }^{33}$ que criamos por convenção.

No parágrafo 27 do citado capítulo, Locke faz referência a esse tipo de problema e lança a seguinte pergunta: Em que consiste os limites precisos e imutáveis das espécies? Ele mesmo responde nos seguintes termos:

É óbvio que, se examinarmos, não existe tal coisa feita pela natureza e estabelecida por ela entre os homens. [...] Tão incertas são as fronteiras das espécies de animais para nós, que não temos outras medidas além das ideias complexas colhidas por nós mesmos: e tão longe nós estamos de saber com certeza o que é um homem; ainda que talvez possa ser julgado como estupidez levantar esse tipo de dúvida. E, no entanto, acho que posso dizer que certos limites dessa espécie estão tão longe de serem determinados, e que o número exato de ideias simples que constituem a essência nominal está tão longe de ser estabelecido e perfeitamente conhecido, que muitas dúvidas materiais ainda podem surgir sobre isso. E imagino que nenhuma das definições da palavra homem que já temos, nem das descrições desse tipo de animal, seja tão perfeita e exata que satisfaça uma pessoa inquisitiva e atenciosa; muito menos que obtenha um

\footnotetext{
${ }^{32}$ Plutão, descoberto em 1930, foi considerado um planeta até 2006. Nesse ano, por convenção, deixou de fazer parte desse grupo de indivíduos que abarca Mercúrio, Vênus, Terra, Marte, etc.

${ }^{33} \mathrm{Um}$ dos principais resultados alcançados no desenvolvimento dessa pesquisa foi a constatação de que as espécies (os universais) não são nada mais que grupos de indivíduos. Nos exemplos citados, Plutão era considerado um elemento (ou um objeto, ou um indivíduo) do grupo planeta.
} 
consentimento geral, e que oriente os homens em todos os lugares, na decisão dos casos e na determinação da vida e da morte, batismo ou não, nas produções que possam ocorrer. $(\mathrm{E} 3,6,27)^{34}$

Desse conjunto de observações, destacamos a lucidez de Locke em constatar que a compreensão dos limites dos termos gerais não é algo tão simples e direto como normalmente pensamos. Utilizamos o termo "homem" tão frequentemente que imaginamos estarmos totalmente seguros sobre seu significado. Mas, na verdade, o que ocorre é que, como explicamos, o centro dos grupos sempre são fáceis de serem identificados, mas, nas bordas, a dificuldade é imensa. Identificar um homem adulto, com uma aparência que podemos chamar de normal, em uma situação normal do dia a dia é tarefa fácil. Mas identificar se um feto, em um determinado momento de seu desenvolvimento no útero, já pode ser considerado um homem - e, portanto, possui os chamados direitos humanos, como a vida -, é um

\footnotetext{
34 "It is plain, if we examine, there is no such thing made by Nature, and established by her amongst men. [...] So uncertain are the boundaries of species of animals to us, who have no other measures than the complex ideas of our own collecting: and so far are we from certainly knowing what a man is ; though perhaps it will be judged great ignorance to make any doubt about it. And yet I think I may say, that the certain boundaries of that species are so far from being determined, and the precise number of simple ideas which make the nominal essence so far from being settled and perfectly known, that very material doubts may still arise about it. And I imagine none of the definitions of the word man which we yet have, nor descriptions of that sort of animal, are so perfect and exact as to satisfy a considerate inquisitive person; much less to obtain a general consent, and to be that which men would everywhere stick by, in the decision of cases, and determining of life and death, baptism or no baptism, in productions that might happen.” (E 3, 6, 27)
} 
desafio ainda não resolvido pela bioética. Todavia, como a maioria das pessoas se mostram de acordo com a classificação da grande maioria dos indivíduos em seus respectivos grupos, nós conseguimos nos comunicar e gerar conhecimento. Mas, para qualquer espécie complexa, aqueles casos que se situam nas margens, são origem de divergências, desentendimentos e conflitos. O que Locke procura salientar é que identificar os limites dos grupos (ou as fronteiras das espécies) é muito mais difícil do que é normalmente considerado pelo senso comum. Isso, segundo ele, não ocorreria se as espécies existissem no mundo real.

No parágrafo doze, Locke segue nesse sentido e refere-se diretamente ao problema das gradações contínuas, na tentativa de finalmente afastar a possibilidade do realismo como um todo:

[...] em todo o mundo corporal visível, não vemos abismos ou lacunas. Em tudo abaixo de nós, a descida se dá por etapas suaves, e em uma série contínua de coisas, que diferem muito pouco uma das outras. Existem peixes que têm asas e não são estranhos em regiões arejadas; e existem alguns pássaros que habitam a água, cujo sangue é frio como o dos peixes, e sua carne é tão saborosa que os escrupulosos os admitem nas pescarias. Existem animais tão próximos tanto dos pássaros quanto das bestas que estão no meio de ambos: animais anfíbios ligam o terrestre e o aquático; as focas vivem na terra e no mar, e os botos têm o sangue quente e as entranhas de um porco[...] $\left(\right.$ E 3, 6, 12). ${ }^{35}$

35 " [...] in all the visible corporeal world, we see no chasms or gaps. All quite down from us the descent is by easy steps, and a continued series of things, that in each remove differ very little one from the other. There are fishes that have wings, and 
Contudo existe uma fragilidade na construção desse argumento. Ele não é suficiente para afastar o realismo aristotélico puro, que sugere a possibilidade das essências reais. O problema é que Locke tenta aplicar a hipótese de gradações contínuas ao que chamaremos de “análise horizontal das espécies”, isto é, a análise das diferenças observáveis nas espécies de seres vivos existentes em determinado ponto da história da evolução do nosso planeta. Mas o que esse tipo de análise nos revela, na verdade, é o contrário: é possível pensar, nesse caso, a existência de essências reais dadas pela natureza. Se analisássemos amostras de DNA de cada ser vivo que existe hoje na Terra, poderíamos dizer, com segurança, quais dessas amostras correspondem à espécie humana, isto é, conseguimos distinguir as espécies com base em sua constituição interna. Isso porque há lacunas nas diferenças de DNA das diversas espécies. Na análise horizontal, não se aplica o conceito de gradações contínuas, como imaginava Locke. Isso ocorre porque nem toda a combinação de genes produz seres vivos capazes de sobreviver no planeta Terra em determinado momento. Portanto, as combinações de genes possíveis de serem

are not strangers to the airy region: and there are some birds that are inhabitants of the water, whose blood is cold as fishes, and their flesh so like in taste that the scrupulous are allowed them on fish-days. There are animals so near of kin both to birds and beasts that they are in the middle between both: amphibious animals link the terrestrial and aquatic together; seals live at land and sea, and porpoises have the warm blood and entrails of a hog." (E 3, 6, 12) 
encontrados na natureza se aglomeram em torno de padrões identificáveis, com pequenas variações entre os indivíduos de uma mesma espécie. Nesse caso a afirmação anterior de Locke - aquela onde ele faz referência à plausibilidade do realismo aristotélico puro - estaria mais de acordo com a realidade.

Porém é possível desenvolver o raciocínio a partir desse ponto, aplicando o problema das gradações contínuas a outras situações, e, assim, argumentar no sentido de uma refutação definitiva do realismo, incluindo o realismo aristotélico puro.

Podemos partir para o que chamaremos de "análise vertical das espécies", ou seja, a análise da evolução das espécies no decorrer do tempo, ou análise da árvore filogenética da vida. Segundo a teoria da evolução de Darwin, todas as espécies se originaram de um ancestral comum. A cada geração existe a possibilidade da ocorrência de uma mutação - pequena variação genética aleatória. Segundo essa teoria, cada mutação representa um passo no longo caminho da evolução. Dessa forma é possível imaginar nossos pais, nossos avós, enfim, uma sequência de indivíduos que são nossos ancestrais, partindo do tempo presente em direção ao passado. Sabemos que o homem e o chimpanzé possuem um ancestral em comum que teria vivido entre 5 e 7 milhões de anos atrás. Chamemos essa espécie de espécie " $X$ ”. Então a seguinte pergunta poderia ser lançada: Qual é o indivíduo (ou quais são os indivíduos), na linha de nossos ancestrais, cujo DNA não pode ser 
considerado humano, mas deve ser considerado da espécie " $\mathrm{X}$ "? Aqui temos uma a situação de gradação contínua. A teoria da evolução não prevê grandes lacunas entre as diferenças de estruturas de DNA ao longo das gerações. A diferença entre o DNA de uma geração que já poderíamos chamar de humana e a geração imediatamente anterior seria muito menor que a diferença entre o DNA dessa geração e aquele que portamos hoje. Não faz sentido classificarmos essa geração como humana e a anterior como pertencente a uma outra espécie. Além disso, essa análise não precisa ficar restrita às estruturas internas. Qualquer característica que pode nos distinguir dos outros animais, inclusive a racionalidade, deve surgir aos poucos ao longo da evolução.

Ademais outros exemplos contra o realismo podem ser formulados. No cerne do problema do aborto está a dificuldade de identificarmos em que momento do desenvolvimento do feto surge um novo ser que podemos classificar como homem. Aqui também temos uma situação de diferenças por gradações contínuas. O desenvolvimento de uma vida humana é um processo contínuo: zygoto, embrião, feto, recém-nascido, criança, adolescente, adulto, idoso etc. No zygoto já temos o DNA do novo ser humano que será formado. Mas é apenas uma célula. Se considerarmos esse momento como o surgimento de um novo homem, surgem vários problemas. $\mathrm{O}$ zygoto tem direito à vida? A todo momento ocorrem abortos espontâneos onde esses tipos de células são descartados pelos 
organismos das mulheres. Precisaríamos realizar funerais? Uma célula humana viva qualquer, digamos, da pele, também possui DNA em sua estrutura interna. Ela também é um homem? Várias outras observações desse tipo poderiam ser feitas. Todos esses casos indicam que o significado do termo geral "homem", se analisamos o processo de evolução de uma vida individual, também é fruto de convenção. A diferença entre um jovem de dezoito anos e ele mesmo um dia antes de completar essa idade é menor que ele mesmo aos dezoito e aos dezenove anos. Por convenção estabelecemos um limite de idade vinculado a direitos e obrigações civis.

A essência do homem, portanto, não está dada pela natureza assim como a essência do adolescente ou a essência do jovem não existem no mundo senão na mente humana e são derivadas de um processo de convenção. O realismo não se aplica a seres complexos, como é o caso do homem.

\section{CONCLUSÃO}

Como vimos, é possível, baseando-nos na proposta de solução de Locke para o problema dos universais e sustentados por evidências científicas atuais, argumentar contra a possibilidade do realismo em geral. Dentro da teoria das ideias abstratas, encontramos um caminho para a rejeição do realismo platônico e mostramos como foi rejeitada a contento a versão escolástica do realismo aristotélico. Além disso 
argumentamos que o realismo como um todo pode ser refutado se considerarmos o problema das gradações contínuas. Pois, apesar de Locke ter falhado ao tentar aplicar esse problema à análise horizontal das espécies, mostramos que as diferenças por gradações contínuas se verificam na análise vertical e no desenvolvimento contínuo da vida em qualquer indivíduo. Essas evidências apontam para uma conclusão importante: a impossibilidade de espécies complexas, como o homem, serem consideradas obras da natureza.

\section{Referências}

LOCKE, John. An Essay concerning Human Understanding. Editado por Peter H. Nidditch. Oxford: Clarendon Press, 1975.

FREGE, Gottlob. Sobre o sentido e a referência. Tradução de Sérgio R. N. Miranda. Rev. de Pesquisa em Filosofia FUNDAMENTO. v. 1, n. 3. 2011. p. 21-44. Disponível em: <https://periodicos.ufop.br:8082/pp/index.php/fundamento/article/vi ew/2271>. Acesso em: 15 mar. 2020.

KLIMA, Gyula. The Medieval Problem of Universals. The Stanford Encyclopedia of Philosophy. Edward N. Zalta (ed.). 2017. Disponível em: <https://plato.stanford.edu/archives/win2017/entries/universalsmedieval/>. Acesso em: 15 mar. 2020.

KUKLOK, Allison. Strings, Physies, and Hogs Bristles: Names, Species, and Classification in Locke. Locke Studies. n. 18, 2018. p.1- 
27.

Disponível

em:

<https://ojs.lib.uwo.ca/index.php/locke/article/view/1512/4005>.

Acesso em: 11 out. 2018.

LOVATTI, Maurilio. General ideas and the knowability of essence: Interpretations of Locke's theory of knowledge. Oxford, Tercentenary John Locke Conference. 2004. p.1-7. Disponível em: <https://philpapers.org/archive/LOVGIA.pdf>. Acesso em: 11 out. 2018.

NEWTON, Jesse. Locke on the 'Species' of Substances. Locke Studies. n. 14, 2014. p.105-120. Disponível em: <https://doi.org/10.5206/ls.2014.720>. Acesso em: 11 out. 2018.

REALE, Giovanni. Aristóteles Metafísica. Tradução de Marcos Marcionilo. São Paulo: Edições Loyola, 2002.

Data de registro: 09/05/2020

Data de aceite: 17/10/2020 